\title{
The research of expectations and perceptions of Individuals towards service quality that are coming to sports center continually
}

\author{
Sihmehmet YIGIT 1, Adnan ERSOY ${ }^{2}$ \\ School of Physical Education and Sports, Namık Kemal University, Tekirdă̆, Turkey. \\ School of Physical Education and Sports, Dumlupinar University, Kütahya, Turkey. \\ Address correspondence to Sihmehmet Yigit, smehmetyigit27@hotmail.com
}

\begin{abstract}
The aim of the research is to explore the expectations and pleasure of members who are coming to sports center continually. The universe of the research and the samples of forming sport centers is made up by the total $(n=259)$ of members who are coming to sports center continually in the city of Gaziantep. To research the views of people coming to sport center about the pleasure towards service quality, the scale developed by Lam, Zhang and Jensen (1), the validity and reliability studies are done by Gürbüz, Koçak and Lam (1) in Turkey SQAS (Service Quality Assessment Scale) the scale of service quality is used. The internal consistency of the scale is tested by Cronbach Alpha techniques. To define the differences between the groups, "independent sample $t$ test" and "the analysis of one way variance" are used. The reliability coefficient of service quality is found above 0.90 . As a result of research; the expectations are higher than perceptions in the evaluation of expectations and perceptions of the individuals who are coming to sport centers regularly, the sports centers are not in the level of meeting the needs of member as service quality.
\end{abstract}

Keywords: Service quality, expectation, perception.

\section{INTRODUCTION}

Developing markets make the service quality important in the activity of enterprises based on physical activity. If the quality of given service is not measured, the quality cannot be improved, so in this situation, the quality that cannot be measured is not a system but it is a slogan (10). That study expressing what kind of perceptions the clients have for the quality of service, has an importance for producing more effective marketing strategy for the enterprises.

First some concepts that are basic for our research will be explained shortly. Service is a concept that it is hard to define it. Most of the services are tangible, and they are tested in a small quantity in advance, they are displayed on showcases, their ads can be done effectively as in the goods, they are not a kind that is perceived by 5 senses and learned easily. Another difficulty of defining and developing the services is to define the need. Because the need for services is more dependent to environmental conditions compared to the need of goods and they are based on seeing and describing rather than feeling those (5). The services as stressed in the description have some features like being intangible, heterogeneous, having simultaneous production and consumption. The features will be explained in details below.

Abstractness; among four characteristics, abstractness is the main source in which others exists, and it differentiates the services from the goods.

The services are performances and struggles. Services are not seen, felt, tested similarly with concrete goods. For example, if we take in hand buying a cinema ticket and buying a pair of shoes; shoes are concrete goods and they can be evaluated objectively before they are bought. It is possible to hold and raise the shoes, check which material is used for it, see its own style, try, being a physical owner of the shoes after buying them. What you get by buying a cinema ticket is the experience. When the film finishes, the consumer will return the house with an experience and being the physical owner of the ticket (4).

Simultaneous production and consumption (Inseparability); the goods are produced with the 
defining of needs and are presented to the consumer. But in the marketing of service, it is not possible to produce the service before presenting them to the customer. So the production and consumption of services are done simultaneously being different from product marketing (3).

Being not homogeneous (Heterogeneity); two different presentations of the same service are not possible to be the same because services are produced by people. The quality and content of services can be differentiate from the one who is producing the service to the other, from one customer of the services to the other, even from day to day. For example; the quality and content of medical examination can be differentiate from one doctor to another, from one patient to another or from day to day. Then, the possibility and facility of being great changes and fluctuation in service performances according to persons, time and stage are always available. A specific marketing problem caused by that feature is the standardization and difficulty of quality-control activities (9).

Weakness; services don't have physical resistance and life span like goods. Services cannot be kept and stockpiled because they supply a performance. Weakness is based on the feature of being unstock able of the services. For example; unused service quality like plane seats that are not purchased in a particular voyage, the theater tickets that cannot be sold, empty hotel rooms, an examination hour that is not filled for a doctor are not evaluated for that time period that will not come again. But the stocking in the goods is available (5).

Possession; while a person buying a good is the owner of it, benefiting from the service is the point in service sector. Benefiting from a hotel room can be given an example to that. Payment is done for using the services, or renting them. The users of the service cannot hand it over. So the users are more dependent to service producer when they buy and use it (8). The aim of the research is to explore the expectations and pleasure of members who are coming to sports center continually.

\section{MATERIAL \& METHOD}

The universe and sample: The universe of the research includes sports centers existing in Gaziantep. 8 sports centers' members are included in the research. Total registered members are 525; the survey is applied to 290 members. It took feedback as the number of scale forms taken in a week is 290. But 259 of these scale forms are identified as being usable and the analysis made by these forms.

Data Collection Tools: In this study, as a tool of data collection SQAS (Service Quality Assessment Scale) is used and it is developed by Lam, Zhang and Jensen (1), its study of reliability and validity is done by Gürbüz, Koçak and Lam (1) in Turkey and it is developed for evaluating the service quality of health and fitness clubs. SQAS is made up from 40 item and six sizes. These are; staff, programme, changing room, physical features, training facility, child care. But the size of child care doesn't take place in the searched fitness center so it is taken out from the scale. For the aim of evaluating the items existing in the scale, the expectations and perceptions taking place in SERQUAL model are used. The first group of scale measures the expectations of customers from a fitness and sport center, the second group measures the performances of fitness and sports center (10).

The statically analysis of data: In the taken data's, frequency, percentage, arithmetic average are analyzed. To define the internal consistency of the scale Cronbach Alpha security coefficient is counted. Also, because of using $t$ a research method based on person's own declaration, 'The only factor method of Horman' is used to define the common method variance exists or not. To define the quality of service method generally, the difference is identified by subtracting the perception scores from expectation scores. To find the differences among the groups, "matched sample $t$ test", "independent sample $t$ test", " one way variance analysis are used. It is accepted as being meaningful in the situation that the difference between them is $\mathrm{p}<0.05$.

\section{RESULTS}

In this part, the findings taken from the participants are given place. In the first part, the frequency and percentage rates take place according to the demographic features of participants, and in the second part, the difference between the perception and expectation of service quality of participants take place. At last, the analysis towards the rating of the service quality of customers take place according to gender, age, marital status, educational status, the time of participating, and the aim of participating.

As seen in table 1 according to the gender variant, male members are (\%76.4) more than females (\%23.6). According to age variant, the rate of 
registration to the sports center of young adulthood members are \%66, adults are \%22.2, and puberties are \%11.2 According to the education level, members are generally university graduated (\% 46.3) and high school graduatede (\%44) but a few of them are elemantary school graduated (\%9.7).

Table 1. Gender, age, period, education, participation and variable time points according to the quality of service of the members are given their analysis.

\begin{tabular}{|c|c|c|c|}
\hline & & $\mathrm{n}$ & $\%$ \\
\hline \multirow[t]{3}{*}{ Gender } & Male & 198 & 76.4 \\
\hline & Female & 61 & 23.6 \\
\hline & Total & 259 & 100 \\
\hline \multirow[t]{5}{*}{ Age periods } & Puberty (between 13-18) & 29 & 11.2 \\
\hline & Young Adulthood (between 19- & & \\
\hline & 30) & 171 & 66 \\
\hline & Adulthood (31- age) & 59 & 22.8 \\
\hline & Total & 259 & 100 \\
\hline \multirow{4}{*}{$\begin{array}{l}\text { Educational } \\
\text { Status }\end{array}$} & Elementary School & 25 & 9.7 \\
\hline & High School & 114 & 44 \\
\hline & University & 120 & 46.3 \\
\hline & Total & 259 & 100 \\
\hline \multirow{6}{*}{$\begin{array}{l}\text { Time of } \\
\text { participating }\end{array}$} & Less than 6 months & 124 & 47.9 \\
\hline & 6 months - 1 Year & 63 & 24.3 \\
\hline & 1-2 Year & 39 & 15.1 \\
\hline & 2-3 Year & 12 & 4.6 \\
\hline & More than 3 years & 21 & 8.1 \\
\hline & Total & 259 & 100 \\
\hline
\end{tabular}

According to the time of participation, the members participating less than six yars are \%47.9, two or three years is $\% 4.6$ and more than three years is \%8.1 and the members participating for a long time is less in number.

In table 2, the reliability coefficient of service quality is determined as above 0.90. It is stated that the size in $0.60<0.80$ are rather reliable, ant the sizes in $0.80<1.00$ are at the level of higher reliability (10). When the differences between the perception and expectation scores are evaluated in terms of items, none of the items meet the expectations of customers. In the form of staff, it is seen that there is lower service quality in kindness, showing special attention to the members, the continuity of services. It is determined that the item of "variety of programme" in the programme size is $-0,18$, "the suitability of programmes" is -0.15 , "background music" is -0.19 , "sufficient place" is -0.22 and they show it has inferior quality and it makes up meaningful differences. In the subdivision of dressing room, it is the theme sports centers having inferior quality at this point; the general maintenance is -0.26 and the clarity of showers is0.23, having no lockers, there is -0.19 differences between access and safety. In the subdivision of physical facility; the sign of being the lowest quality are the safety of parking place is -0.35 , the control of temperature, having no parking place is -0.33 , "the light control" is -0.26 , "the time of facility" is -0.20 , and the suitability of place is -0.18 , access to the building is -0.18 . In the subdivision of training facility; the signs of having lower quality are these; the general maintenance is -0.22 , "having training facility/equipment" is -0.19 , "the qualifications of sign and instructions" is -0.17 and "the variety of devices" is -0.15 , the attractiveness of atmosphere is -0.15 and devices in the modern is -0.13 .

When it is evaluated in terms of different sizes between expectation and perception scores, it is stated that every sizes have negative meaning statically. Among them physical facility having -0.26 unit is seen as in the lowest quality level. And then in order; the dressing room with -0.20 unit difference the personnel size with -0.17unit difference the size "training facility" with -0.14unit difference. When the service quality is evaluated generally, it is stated that there is -0.20 units between perception and expectation in negative way.

The average standard deviation, $T$ values, reliability Coefficient of members towards service quality

The reliability coefficient of service quality sizes is identified as above 0.90 . The reliability coefficient of service quality sizes, the level $0.60<0.80$ shows the sizes are quite reliable, the level $0.80<1.00$ is highly valuable (1). When the differences between perception and expectation are evaluated in terms of items; none of the items is seen as meeting the needs of members. In the subdivision of staff the continuity of kindness, showing special attention to the members, showing the service are in the $\mathrm{p}<0.01$ level, other items are in $\mathrm{p}<0.001$ level and they all show lower service quality. The item of programme diversity is shown in the lower level with "programmmes being suitable", "background music", "enough space" $(p<0.001$ and they are shown having a meaningful difference in $\mathrm{p}<0.01$ level. In the subdivision of dressing room; general maintains and the cleaning of showers have the lowest quality level, having no lockers, the differences in access and safety show that sports centers have the lowest service quality in $p<0.001$ level. In the physical facility subdivision; the items of the safety of parking place, temperature control, 
having no car parks, the light control, time of activities show the lowest quality with $\mathrm{p}<0.001$, "the suitability of the place" access to the building in the level of $p<0.01$ again show the lower quality of services. In the subdivision of training facility; the general maintenance, training facility/having enough equipment, the qualification of signs and instructions are in the level of $p<0.001$, "the attractiveness of the atmosphere" and "equipment in the modern form" are in the level of $p<0.01$ and they show lower service quality. When the differences between perception and expectations are evaluated in terms of different sizes, it is determined that all the sizes have a meaningful difference in negative way statically. Among them the size having the lowest service quality is physical facility. And then in order; dressing room size, staff size, training facility size and at last the programme size. When the service quality is evaluated generally, it is determined that there is -0.20 unit differences between perception and expectation and this difference is in the negative way, there is a meaningful difference in the $p<0.001$ level in terms of statistical.

Table 2. The average standard deviation and reliability coefficient belonging to the expectations and perceptions of members about the service quality.

\begin{tabular}{|c|c|c|c|c|c|c|c|c|}
\hline & & \multicolumn{2}{|c|}{ Perception } & \multicolumn{2}{|c|}{ Expectation } & \multicolumn{3}{|c|}{ Servqual score } \\
\hline & & $X$ & SS & $X$ & SS & A-B & Extent & Total \\
\hline \multirow[t]{10}{*}{ Staff } & 1.Having necessary information and skill & 4.41 & 0.52 & 4.70 & 0.46 & -0.29 & -0.20 & -0.20 \\
\hline & 2. Cleaning and neat clothing & 4.41 & 0.50 & 4.68 & 0.48 & -0.27 & & \\
\hline & 3. Willigness of helping & 4.39 & 0.52 & 4.67 & 0.48 & -0.28 & & \\
\hline & 4. Patience & 4.42 & 0.53 & 4.59 & 0.51 & -0.17 & & \\
\hline & 5. Interaction with members & 4.39 & 0.55 & 4.59 & 0.51 & -0.19 & & \\
\hline & 6. Sensitivity toward complaints & 4.39 & 0.51 & 4.59 & 0.51 & -0.20 & & \\
\hline & 7. Kindness & 4.40 & 0.58 & 4.54 & 0.56 & -0.14 & & \\
\hline & 8. Showing special attention to the customers & 4.38 & 0.57 & 4.51 & 0.61 & -0.13 & & \\
\hline & 9. The continuity of showing service & 4.38 & 0.54 & 4.53 & 0.57 & -0.15 & & \\
\hline & Cronbach Alpha & .939 & & .919 & & & & \\
\hline \multirow[t]{8}{*}{ Programme } & 10. The variety of programmes & 4.32 & 0.63 & 4.50 & 0.61 & -0.18 & -0.14 & \\
\hline & 11.programmes being in appropriate level & 4.33 & 0.60 & 4.48 & 0.59 & -0.15 & & \\
\hline & 12. the suitability of programme time chart & 4.32 & 0.62 & 4.41 & 0.63 & -0.10 & & \\
\hline & 13. The quality of programme's context & 4.30 & 0.66 & 4.39 & 0.65 & -0.09 & & \\
\hline & 14. the suitability of classroom's size & 4.25 & 0.68 & 4.34 & 0.69 & -0.08 & & \\
\hline & 15.Background music(if there is) & 4.19 & 0.78 & 4.38 & 0.70 & -0.19 & & \\
\hline & 16. Sufficient area & 4.24 & 0.68 & 4.46 & 0.59 & -0.22 & & \\
\hline & Cronbach Alpha & .922 & & .911 & & & & \\
\hline \multirow[t]{6}{*}{ Dressing room } & 17. Having lockers & 4.50 & 0.66 & 4.69 & 0.52 & -0.19 & -0.21 & \\
\hline & 18.General maintenance & 4.45 & 0.65 & 4.71 & 0.47 & -0.26 & & \\
\hline & 19. The cleanity of shower & 4.49 & 0.62 & 4.71 & 0.46 & -0.23 & & \\
\hline & 20.Access & 4.50 & 0.61 & 4.69 & 0.50 & -0.19 & & \\
\hline & 21. Safety & 4.53 & 0.57 & 4.71 & 0.47 & -0.19 & & \\
\hline & Cronbach Alpha & .918 & & .931 & & & & \\
\hline \multirow[t]{8}{*}{ Physical facility } & 22. The suitability of place & 4.27 & 0.68 & 4.46 & 0.56 & -0.18 & -0.26 & \\
\hline & 23. time of activities & 4.22 & 0.70 & 4.41 & 0.57 & -0.20 & & \\
\hline & 24. Having car parking & 3.93 & 0.99 & 4.26 & 0.77 & -0.33 & & \\
\hline & 25. access to the building & 4.17 & 0.80 & 4.36 & 0.61 & -0.18 & & \\
\hline & 26.the safety of parking place & 4.00 & 0.95 & 4.35 & 0.67 & -0.35 & & \\
\hline & 27. The control of temperature & 4.07 & 0.86 & 4.42 & 0.63 & -0.35 & & \\
\hline & 28.The control of lights & 4.14 & 0.81 & 4.41 & 0.62 & -0.26 & & \\
\hline & Cronbach Alpha & .901 & & .917 & & & & \\
\hline \multirow[t]{8}{*}{ Training facility } & 29. The attractiveness of ambiance & 4.42 & 0.57 & 4.57 & 0.58 & -0.15 & -0.17 & \\
\hline & 30. The equipment in the modern form & 4.40 & 0.64 & 4.53 & 0.63 & -0.13 & & \\
\hline & 31.The sufficiency of sign and instructions & 4.37 & 0.62 & 4.55 & 0.53 & -0.17 & & \\
\hline & 32. The variety of equipment & 4.47 & 0.54 & 4.62 & 0.50 & -0.15 & & \\
\hline & 33.having training facility/equipment & 4.41 & 0.53 & 4.60 & 0.50 & -0.19 & & \\
\hline & 34. General maintenance & 4.42 & 0.57 & 4.64 & 0.49 & -0.22 & & \\
\hline & Cronbach Alpha & .930 & & .931 & & & & \\
\hline & General Service quality & 4.33 & .36 & 4.53 & 0.30 & -0.20 & & \\
\hline
\end{tabular}




\section{DISCUSSION}

In the result of study, the findings below are reached, and they are evaluated by comparing some studies taken place in literature; gender, age, marital status and education level are compared. When it is seen in terms of differences, in this study; males who are continually going to the sports center are more than females (2). States that males are more than females in the distribution of sports centers choice and the participation of females is less in his study. As in the same way; (12) states that \%57 of the participations are male and \%43 of them is females in the study of 2007. Based on that it can be said that males have much more participation than females in terms of sport activities. Age: about the members who are registered to the sport centers young adults are the most, then comes adults and the lest is adolescences. In the study of (12) it is seen that the number of young adults are more than others. Marital status: most of the members who are participating to the sport centers are singles. Education level: the members are mostly university or high school graduated, and there is a few primary schools graduated (13). When the education level of employees is examined university graduated are much more and at the lowest rate of them are primary school graduated. Participating time: most of the members participate the sport center less than 6 months, the new members are 2-3 years and more than three years is at the lower number. (14) Most of the members' participation time is between 6 months and 2 years. Generally, most of the members participating fitness and sports centers are malls, young adults, single and university graduated. Their participating time is less than 6 months and they prefer sports centers for the purpose of being healthy and keeping fit. In the other literature studies only (14), made difference in that point female members are in the same with males. The other studies are in the same way. The expectations of young adults are much more than adults in terms of dressing room, training facility of sports centers. At the same time in terms of member's expectation from the staff, the young adults have much more expectations than adults and adolescences. In addition; the expectations of members according to the age in terms of physical facility do not become different. In the result of statistical analysis; there is no meaningful differences in terms of participation time in the subdivision of service quality ( $P>0.05)$. There are no meaningful differences in the aims of customers participating the sport centers in the service quality scales and subdivisions.
In the result of the study; although the scores of females are more than the scores of males according to gender, at the end of the t-test, there is no difference in t-test about the general service quality $\left(t_{(258)}=1.553, p>0.05\right)$. There is no difference between $t$ tests results. According to age, the scores of young adults about the service quality are much more than adults and adolescents meaningfully. According to the education level variable, the scores of staff expectations; the scores of university graduated are much more than high school and primary school graduated. The results of the test show there is no meaningful differences in the comparetion of general service quality subdivision $\left(\mathrm{F}_{4.258}=0.73\right.$, $\mathrm{P}>0.05$ ). As a result; in the evaluations of members' expectation and perceptions; the expectations are much more than perceptions the sport center is not in the level of meeting the needs of members with its general sizes.

\section{KAYNAKLAR}

1. Akgül A, Çevik O. İstatistiksel Analiz Teknikleri SPSS'te İşletme Yönetimi Uygulamaları, 2003.

2. Çoban B. Spor Hizmetlerine İlişkin Halkın Belediyelerden Beklentileri (Elazığ Belediyesi Örneği). Gazi Üniversitesi, Sağlık Bilimleri Enstitüsü, Yayımlanmamış Doktora Tezi, Ankara, 2002.

3. Fitzgerald TJ. Understanding the Differences and similarities between services and products to exploit your competitive advantage. The Journal of Services Marketing, 1988; 2(1): 25-30.

4. Hoffman KD, Bateson JEG. Essentials of Services Marketing. Orlando: The Dryden Press, 1997.

5. İslamoğlu AH, Candan B, Efendioğlu ŞH, Aydın K. Hizmet Pazarlaması. İstanbul: Beta Basım Yayım Dağıtım A.Ş., 2006.

6. İslamoğlu AH. Hizmet pazarlamasinda ürün politikalar1. Pazarlama Dünyası, 1995; 9(50): 3-5.

7. Lam ETC, Zhang JJ, Jensen BE. Service Quality Assessment Scale (Sqas): An instrument for evaluating service quality of health-fitness clubs. Measurement in Physical Education and Exercise Science, 2005; 9(2): 79-111.

8. Odabaşı Y. Sağlık Hizmetleri Pazarlaması. Eskişehir: Anadolu Üniversitesi Açıöğretim Fakültesi, Yayın No:409, 1994.

9. Öztürk SA. Hizmet Pazarlaması, $4^{\text {th }}$ ed., Bursa: Ekin Publishing, 2003.

10. Parasuraman A, Zeithaml VA, Berry LL. A Conceptual model of service quality and its implications for future research. Journal of Marketing, 1985; 49(4): 41-50.

11. Parasuraman A, Zeithaml VA, Berry LL. Servqual: a multipleitem scale for measuring consumer perceptions of service quality. Journal of Retailing, 1988; 64(1): 12-40.

12. Uçan Y. Spor-Fitness Merkezlerinin Algllanan Hizmet Kalitesi Ölçeğinin Geliştirilmesi, Abant İzzet Baysal Üniversitesi, Sosyal Bilimler Enstitüsü, Yayımlanmamış Doktora Tezi, Bolu, 2007.

13. Ürer B. Spor Hizmeti Verilen Kurumlarda İletişimde Öneri Sisteminin Yönetim ve Organizasyon Açısından Önemi. 
Dumlupınar Üniversitesi, Sağlık Bilimleri Enstitüsü, Yayımlanmamış Yüksek Lisans Tezi, Kütahya, 2009.

14. Yıldız SM, Tüfekçi Ö. Fitness Merkezi Müşterilerinin Hizmet Kalitesine Yönelik Beklenti Ve Algılarının Değerlendirilmesi, Balıkesir Üniversitesi Sosyal Bilimler Enstitüsü Dergisi, 2010; 13(24): 1-11. 